(c) American Dairy Science Association, 2006.

\title{
Direct-Fed Microbial Supplementation on Ruminal Digestion, Health, and Performance of Pre- and Postpartum Dairy Cattle
}

\author{
J. E. Nocek ${ }^{\star 1}$ and W. P. Kautz† \\ *Spruce Haven Farm and Research Center, Union Springs, NY 13160 \\ †Chr. Hansen's Biosystems, Milwaukee, WI 53214-4298
}

\section{ABSTRACT}

Effects of supplementing direct-fed microbial agents (DFM) to dairy cows during the transition period were evaluated. Forty-four Holstein cows were fed close-up and lactating diets that did or did not contain $2 \mathrm{~g}$ of $\mathrm{DFM} /$ cow per d. Direct-fed microbial supplementation contained approximately $5 \times 10^{9} \mathrm{cfu}$ of yeast and 5 $\times 10^{9}$ cfu of bacteria (2 specific Enterococcus faecium strains) incorporated into a cornmeal carrier. Supplemented cows were fed the DFM $21 \mathrm{~d}$ prior to expected calving date through $10 \mathrm{wk}$ postpartum. Cows supplemented with DFM had higher estimated ruminally available dry matter (DM) for both corn silage and haylage than did control cows. Supplemented cows consumed more DM during both the pre- and postpartum periods. In addition, those supplemented with DFM produced $2.3 \mathrm{~kg}$ more milk/cow per d than did nonsupplemented cows. There was no difference in $3.5 \%$ fatcorrected milk. Milk fat percentage was lower, but not depressed (4.76 vs. $4.44 \%$ ) for cows receiving DFM. There were no differences in milk fat yield or milk protein percentage and yield. Cows consuming DFM had higher blood glucose postpartum, as well as lower $\beta$ hydroxybutyrate levels both prepartum and on $\mathrm{d} 1$ postpartum. Plasma nonesterified fatty acid concentration was not statistically affected by DFM, but was numerically lower prepartum and higher postpartum for supplemented cows. This study demonstrated that targeted DFM supplementation enhanced ruminal digestion of forage DM. Early lactation cows receiving supplemental DFM produced more milk and consumed more DM during the pre- and postpartum periods. Cows consuming DFM, however, experienced a lower, but not depressed, fat percentage compared with nonsupplemented cows.

Key words: direct-fed microbial agent, ruminal digestion, production

Received March 16, 2005.

Accepted August 30, 2005

${ }^{1}$ Corresponding author: jimnocek@worldnet.att.net

\section{INTRODUCTION}

The supplementation of direct-fed microbial agents (DFM) in dairy rations has become a generally accepted practice with the following stated benefits: increased ruminal digestion, DMI, and milk production and reduced body temperature (Piva et al., 1993; Higginbotham et al., 1994; McGilliard and Stallings, 1998). The term DFM has included specific and nonspecific yeast, fungi, bacteria, cell fragments, and filtrates (Beharka and Nagaraja, 1993; Sullivan and Martin, 1999; Knowlton et al., 2002). Modes of action are variable and include native rumen microbiota enhancement through increased substrate breakdown, enhancement of nutrient uptake, and provision of growth factors (Martin and Nesbit, 1992). Controlled studies have shown that specific combinations of Enterococcus strains, selected for a unique action in the rumen environment, raised nadir $\mathrm{pH}$ in the rumen, increased mean rumen $\mathrm{pH}$, and increased the mean low daily $\mathrm{pH}$ (Nocek et al., 2002). This specific combination of Enterococcus faecium strains has also shown increased prepartum intake as well as postpartum production in high-producing dairy cattle (Nocek et al., 2003). The rationale for this response may be associated with the production of tonic levels of lactate, which would allow fastidious lactic acid-utilizing microbes to sustain a metabolically active population. This would enable the utilizers to sequester more lactate at specific times when concentrations fluctuate as a result of diurnal feeding behavior. Further confirmation of these results is important in establishing this concept. The objective of this study is to further evaluate the effect of a DFM in dairy cows diets during the transition period.

\section{MATERIALS AND METHODS}

Forty-four multiparous Holstein cows were blocked by previous lactation 305-d mature equivalent milk yield into 2 treatment groups to start on the study 21 $\pm 3 \mathrm{~d}$ before expected calving date and continue through 10 wk postpartum. They were fed a TMR ad libitum once daily. On the day after calving, cows were switched to the appropriate postpartum treatment TMR, which 
Table 1. Ration composition for diets offered $21 \mathrm{~d}$ prepartum through parturition and $10 \mathrm{wk}$ postpartum ${ }^{1}$

\begin{tabular}{lcc}
\hline Ingredient & Prepartum & Postpartum \\
\hline Mixed haylage & 51.2 & 9.8 \\
Corn silage & 27.6 & 43.7 \\
Corn meal & 8.7 & 16.5 \\
Chocolate-sugar blend $^{2}$ & - & 3.4 \\
Roasted soybeans $^{3}$ & - & 6.9 \\
Rumen-inert fat $^{3}$ & - & 0.4 \\
Protein, vitamin, and mineral premix & - & 17.9 \\
Prepartum supplement & & - \\
Limestone & 10.1 & 1.4 \\
Nutrient & 2.4 & \\
CP, \% & 16.3 & 18.4 \\
Degradable intake protein, \% of CP & 67.5 & 58.2 \\
Undegradable intake protein, \% of CP & 33.5 & 41.8 \\
NE, Mcal/kg & 1.50 & 1.80 \\
NDF, \% & 42.1 & 30.6 \\
NFC, \% & 31.2 & 40.6 \\
Fat, \% & 3.4 & 4.6 \\
Ca,\% & 1.86 & 1.1 \\
P,\% & 0.42 & 0.40 \\
Mg, \% & 0.34 & 0.42 \\
\hline
\end{tabular}

${ }^{1}$ Offered either with or without 2 g of direct-fed microbial (DFM; Probios TC, Chr. Hansen, Milwaukee, WI)/d incorporated into 0.454 $\mathrm{kg}$ of cornmeal/cow per d. The DFM contained $5 \times 10^{9} \mathrm{cfu}$ of yeast and $5 \times 10^{9} \mathrm{cfu}$ of bacteria ( 2 specific Enterococcus faecium strains).

${ }^{2}$ Ground chocolate and processed cane sugar: 67:33.

${ }^{3}$ Megalac (Church and Dwight Co., Piscataway, NJ).

${ }^{4} \mathrm{Mix}$ nutrient specification: $46 \% \mathrm{CP}, 19.5 \%$ soluble protein, $2.18 \%$ fat, $1.00 \% \mathrm{Ca}, 0.94 \% \mathrm{P}, 1.42 \% \mathrm{Mg}, 2.43 \% \mathrm{~K}, 0.70 \% \mathrm{~S}, 2.53 \% \mathrm{Na}$, $2.27 \% \mathrm{Cl}, 423 \mathrm{ppm}$ of $\mathrm{Zn}, 88.2 \mathrm{ppm}$ of $\mathrm{Cu}, 110 \mathrm{ppm}$ of $\mathrm{Mn}, 9.7 \mathrm{ppm}$ of Co.

${ }^{5}$ Prepartum supplemement nutrient specification: $52.0 \% \mathrm{CP}, 37 \%$ soluble protein, $2.72 \%$ fat, $1.69 \% \mathrm{Ca}, 1.58 \% \mathrm{P}, 2.37 \% \mathrm{Mg}, 1.30 \% \mathrm{~K}$, $2.35 \% \mathrm{~S}, 324 \mathrm{ppm}$ of $\mathrm{Zn}, 98 \mathrm{ppm}$ of $\mathrm{Cu}, 202 \mathrm{ppm}$ of $\mathrm{Mn}$, and $9.7 \mathrm{ppm}$ of Co.

was also fed once daily ad libitum. The treatments were control (prepartum and postpartum TMR with no DFM supplementation) or DFM [control prepartum and postpartum TMR with inclusion of $2 \mathrm{~g}$ of DFM/cow per d (Probios TC, Chr. Hansen, Milwaukee, WI), Biomate yeast plus ( $1 \mathrm{~g} ; 5 \times 10^{9} \mathrm{cfu}$; Chr. Hansen), and 2 Enterococcos strains $\left(5 \times 10^{9} \mathrm{cfu}\right)$ in both periods]. The DFM was premixed in cornmeal, which was incorporated into the close-up and lactating cow diets at a rate of 0.45 $\mathrm{kg} / \mathrm{d}$. The control cows received cornmeal without the DFM. Ingredient and nutrient compositions of the diets fed during the experimental periods are listed in Table 1 . Feeds were sampled weekly throughout the experiment. Forage quantity fed was adjusted weekly, if needed, based on DM determination. Feedstuffs were composited monthly and analyzed for $\mathrm{CP}, \mathrm{NDF}$, ether extract, and minerals by wet chemistry methods (DairyOne Laboratories, Ithaca, NY).

Production data measured included the following: daily milk weights (twice daily at 0700 and $1900 \mathrm{~h}$ ) and milk composition (samples collected on Monday p.m. and Tuesday a.m. for $10 \mathrm{wk}$ ). Milk fat, CP, MUN, lac- tose, and SCC measurements were taken at the DairyOne Laboratories by infrared spectroscopy on composite a.m.-p.m. samples. Feed offerings and orts were recorded daily for determination of DMI. Body weights and BCS were recorded $21 \pm 3$ before calving, before calving, after calving, and at trial termination. The following health items were recorded for all cows: retained placenta (a placenta that had been retained for $>12 \mathrm{~h}$ ), metritis (a uterine condition diagnosed by either a vaginal discharge or rectal palpation), ketosis (ketones detected in the urine by keto-strips at a high level), and displaced abomasum (diagnosed as gas accumulation as detected by percussion with a stethoscope on the left or right side). Blood was drawn from the first 14 cows per treatment on $\mathrm{d} 1$ prior to expected calving date and on $d 1$ and 7 postcalving. Samples were analyzed for glucose, BHBA, and NEFA. Glucose was determined by the enzymatic analysis (glucose oxidase) using the commercial kit (kit 510-A; Sigma Chemical, St. Louis, MO). Concentrations of NEFA were analyzed by enzymatic analysis (NEFA-C, WAKO Pure Chemicals Industries, Osaka, Japan) using modifications described by McCutcheon and Bauman (1986) and Sechen et al. (1990). Concentrations of BHBA were quantified (BHBA dehydrogenase) using a kit (kit 310UV, Sigma Chemical).

The in situ procedure (Nocek, 1988) used rumen digestibility time points of $0,2,4,6,12,24,48$, and 72 h. Dry matter digestibilities were conducted on corn silage and haycrop silage in 2 ruminally canulated cows (one cow per treatment) at 3 different times between wk 4 and 6 of lactation. Evaluations were conducted on the residues to determine the relative proportion of "a" (water soluble, $53-\mu \mathrm{m}$ filterable), "b" [insoluble digestible: $100-(\mathrm{a}+\mathrm{c})$ ], and "c" (100- to 72-h residual) fractions; KdB was the rate of "b" fraction digestion, and overall estimated ruminally available DM was determined utilizing the equation of Van Soest et al.(1982).

Statistical analyses were conducted using SAS JMP (1996) utilizing split-plot in time ANOVA for repeated measures. The model used was as follows: $\mu=$ mean + treatment + week + cow (treatment) + residual error. For blood and undigested feed residues, no repeated measures were used. Simple one-way ANOVA was conducted to evaluate differences between treatments. Health data with dichotomous outcomes, such as retained placentas, metritis, ketosis, and displaced abomasums, were all analyzed by logistic regression (Stokes et al., 1995) according to a model that included the observed outcome, treatment, and week of lactation.

\section{RESULTS}

Ruminally undegradable DM at specific digestion points was generally lower for cows supplemented with 
Table 2. Effect of direct-fed microbial ${ }^{1}$ (DFM) supplementation on in situ undegraded forage DM

\begin{tabular}{|c|c|c|c|c|}
\hline \multirow[b]{2}{*}{ Hour } & \multicolumn{2}{|c|}{ Treatment } & \multirow[b]{2}{*}{ SEM } & \multirow[b]{2}{*}{$P<$} \\
\hline & $\begin{array}{l}\text { Control } \\
(\mathrm{n}=3)\end{array}$ & $\begin{array}{l}\text { DFM } \\
(\mathrm{n}=3)\end{array}$ & & \\
\hline & \multicolumn{3}{|c|}{ Corn silage (\% undegraded) } & \\
\hline 0 & 59.6 & 58.6 & 0.4 & NS \\
\hline 2 & 56.8 & 54.9 & 0.6 & 0.10 \\
\hline 4 & 53.1 & 54.9 & 1.4 & NS \\
\hline 6 & 53.9 & 51.6 & 1.2 & NS \\
\hline 12 & 53.9 & 48.2 & 1.4 & 0.05 \\
\hline 24 & 46.7 & 40.8 & 0.8 & 0.01 \\
\hline 48 & 34.4 & 27.4 & 1.0 & 0.01 \\
\hline \multirow[t]{2}{*}{72} & 28.6 & 22.1 & 0.5 & 0.01 \\
\hline & \multicolumn{3}{|c|}{ - Haylage (\% undegraded) } & \\
\hline 0 & 73.0 & 71.2 & 0.7 & NS \\
\hline 2 & 72.9 & 70.3 & 0.2 & 0.01 \\
\hline 4 & 69.3 & 69.7 & 1.0 & NS \\
\hline 6 & 71.6 & 65.9 & 1.3 & 0.05 \\
\hline 12 & 70.6 & 64.1 & 0.8 & 0.01 \\
\hline 24 & 59.8 & 51.3 & 0.9 & 0.01 \\
\hline 48 & 48.8 & 45.3 & 0.8 & 0.05 \\
\hline 72 & 45.7 & 40.9 & 0.6 & 0.01 \\
\hline
\end{tabular}

${ }^{1}$ Probios TC (Chr. Hansen, Milwaukee, WI). The DFM contained $5 \times 10^{9} \mathrm{cfu}$ of yeast and $5 \times 10^{9} \mathrm{cfu}$ of bacteria ( 2 specific Enterococcus faecium strains),

DFM compared with control cows for corn silage and haylage (Table 2). The undegradable fraction at $72 \mathrm{~h}$ ("c") was lower $(P<0.05)$, and estimated ruminally available DM was higher $(P<0.05)$, for both forages for cows supplemented with DFM (Table 3). There was no effect of DFM supplementation on ruminal digestion rate.

Table 3. Effect of direct-fed microbial ${ }^{1}$ (DFM) supplementation on in situ digestion pools, rate of forage DM digestion, and estimated ruminally available DM (ERADM)

\begin{tabular}{|c|c|c|c|c|}
\hline \multirow[b]{2}{*}{ Variable $^{2}$} & \multicolumn{2}{|c|}{ Treatment } & \multirow[b]{2}{*}{ SEM } & \multirow[b]{2}{*}{$P<$} \\
\hline & $\begin{array}{l}\text { Control } \\
(\mathrm{n}=3)\end{array}$ & $\begin{array}{l}\text { DFM } \\
(\mathrm{n}=3)\end{array}$ & & \\
\hline & & Corn silage & - & \\
\hline$a, \%$ & 40.2 & 41.6 & 0.5 & NS \\
\hline$b, \%$ & 22.3 & 24.9 & 1.0 & NS \\
\hline c, $\%$ & 37.5 & 33.5 & 0.5 & 0.01 \\
\hline $\mathrm{KdB}, \% / \mathrm{h}$ & 4.57 & 4.28 & 0.3 & NS \\
\hline ERADM, \% & 53.5 & 58.9 & 0.8 & 0.01 \\
\hline a, \% & 40.4 & 41.4 & 0.4 & NS \\
\hline b, $\%$ & 31.0 & 36.6 & 0.4 & 0.01 \\
\hline c, $\%$ & 28.6 & 22.0 & 0.5 & 0.01 \\
\hline $\mathrm{KdB}, \% / \mathrm{h}$ & 3.37 & 3.91 & 0.3 & NS \\
\hline ERADM, \% & 50.5 & 53.0 & 0.4 & 0.05 \\
\hline
\end{tabular}

${ }^{1}$ Probios TC (Chr. Hansen, Milwaukee, WI). The DFM contained $5 \times 10^{9} \mathrm{cfu}$ of yeast and $5 \times 10^{9} \mathrm{cfu}$ of bacteria ( 2 specific Enterococcus faecium strains).

${ }^{2} \mathrm{a}=$ water-soluble, $53-\mu \mathrm{m}$ filterable fraction; $\mathrm{b}=$ insoluble digestible fraction; $c=100$ - to $72-h$ residual fraction; $k d B=$ rate of "b" fraction digestion.
Table 4. The effect of direct-fed microbial ${ }^{1}$ (DFM) supplementation on pre- and postpartum DMI and production responses through wk 10 postpartum

\begin{tabular}{lcccc}
\hline & \multicolumn{2}{c}{ Treatment $^{2}$} & & \\
\cline { 2 - 3 } & $\begin{array}{l}\text { Control } \\
\text { Variable }\end{array}$ & $\begin{array}{c}\text { DFM } \\
(\mathrm{n}=22)\end{array}$ & SEM & $P<$ \\
\hline DMI prepartum, kg $\mathrm{kg}^{3}$ & 10.3 & 11.3 & 0.30 & 0.10 \\
DMI postpartum, kg & 20.0 & 22.7 & 0.30 & 0.01 \\
Yield/d & & & & \\
Milk, kg & 36.9 & 39.2 & 0.5 & 0.01 \\
3.5\% FCM, kg & 44.7 & 45.2 & 0.9 & NS \\
Fat, kg & 1.81 & 1.76 & 0.04 & NS \\
Protein, kg & 1.14 & 1.20 & 0.02 & NS \\
Composition & 4.76 & 4.44 & 0.09 & 0.01 \\
Fat, \% & 3.12 & 3.13 & 0.06 & NS \\
Protein, \% & 210 & 154 & 26 & NS \\
SCC, cells/mL $\times 10^{3}$ & 4.59 & 4.65 & 0.02 & 0.05 \\
Lactose, \% & 12.5 & 12.0 & .22 & NS \\
MUN, mg/dL & & & & \\
\hline
\end{tabular}

${ }^{1}$ Probios TC (Chr. Hansen, Milwaukee, WI). The DFM contained $5 \times 10^{9} \mathrm{cfu}$ of yeast and $5 \times 10^{9} \mathrm{cfu}$ of bacteria ( 2 specific Enterococcus faecium strains).

${ }^{2}$ Cows received treatment from $21 \pm 3 \mathrm{~d}$ prior to expected calving date through wk 10 postpartum.

${ }^{3}$ Mean of $3 \mathrm{wk}$ prior to expected calving date.

Cows supplemented with DFM consumed $1.0 \mathrm{~kg} / \mathrm{d}$ more $(P<0.10) \mathrm{DM}$ during the prepartum period than did control cows (Table 4). During wk -1 precalving, supplemented cows consumed $1.2 \mathrm{~kg}$ more DM than did non-supplemented cows (Figure 1). Postpartum intakes were also higher $(P<0.01)$ for DFM-supplemented cows. Milk yield was higher $(P<0.01)$ for cows receiving DFM compared with control cows (Figure 2). However, there was no difference between supplemented and non-supplemented cows for 3.5\% FCM.

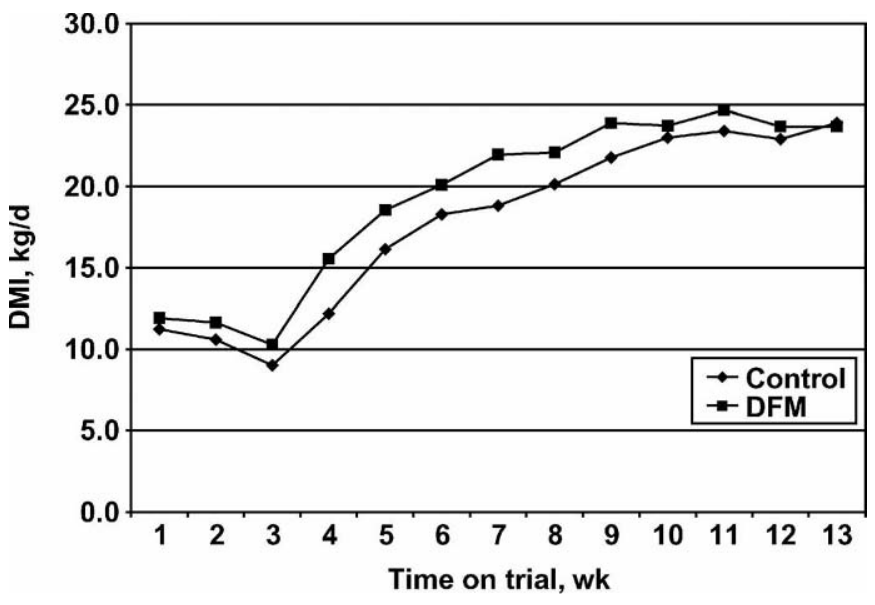

Figure 1. Effect of direct-fed microbial (DFM) supplementation on weekly pre- and postpartum DMI. The DFM contained $5 \times 10^{9} \mathrm{cfu}$ of yeast and $5 \times 10^{9} \mathrm{cfu}$ of bacteria ( 2 specific Enterococcus faecium strains). 


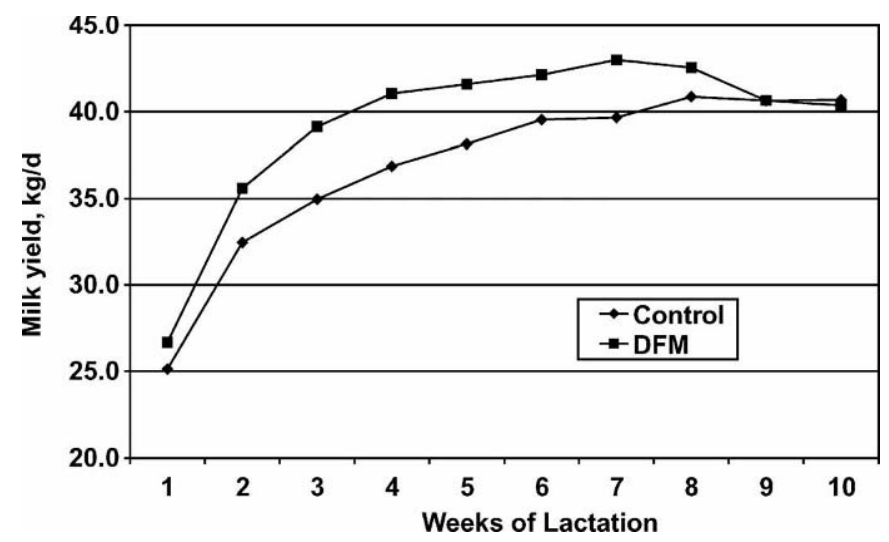

Figure 2. Effect of direct-fed microbial (DFM) supplementation on weekly milk yield. The DFM contained $5 \times 10^{9} \mathrm{cfu}$ of yeast and 5 $\times 10^{9}$ cfu of bacteria ( 2 specific Enterococcus faecium strains).

Fat percentage was lower $(P<0.01)$ for cows receiving DFM compared with controls (Table 4). Primary differences were associated with the first 2 wk postpartum (Figure 3). The milk percentage was not depressed and was $>4.0 \%$. Milk fat yield was not affected by DFM supplementation.

There was no treatment effect on milk protein percentage. Protein yield was not statistically $(P>0.10)$ affected, but was numerically higher for cows consuming DFM compared with controls. There was no effect of treatment on SCC or MUN. Cows supplemented with DFM had a higher $(P<0.05)$ lactose percentage compared with controls.

There was no effect of treatment on BW change or BCS either prepartum or postpartum (Table 5). Control cows starting the study were approximately $44 \mathrm{~kg}$ heav-

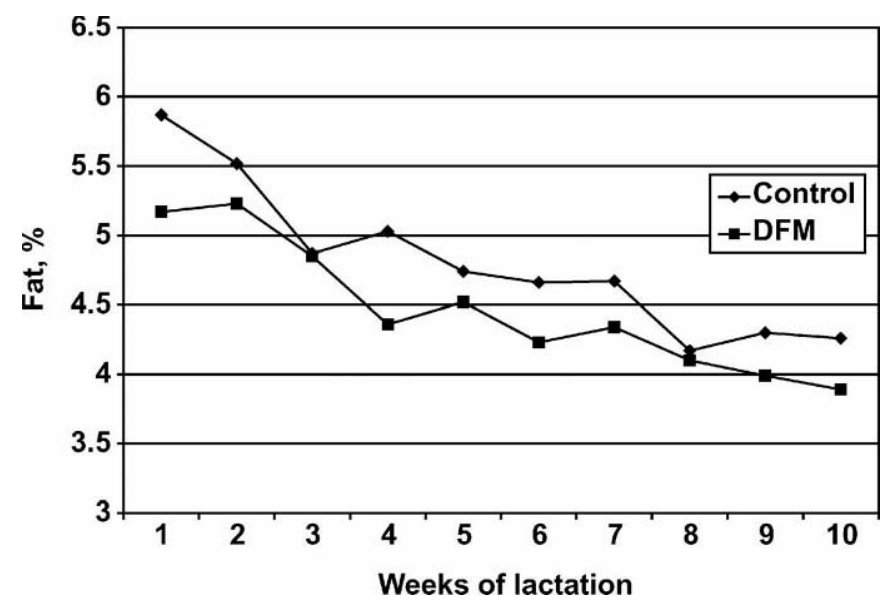

Figure 3. Effect of direct-fed microbial (DFM) supplementation on weekly milk fat percentage. The DFM contained $5 \times 10^{9} \mathrm{cfu}$ of yeast and $5 \times 10^{9}$ cfu of bacteria ( 2 specific Enterococcus faecium strains).
Table 5. The effect of direct-fed microbial ${ }^{1}$ (DFM) supplementation on pre- and postpartum BW and BCS

\begin{tabular}{|c|c|c|c|c|}
\hline & \multicolumn{2}{|c|}{ Treatment ${ }^{2}$} & \multirow[b]{2}{*}{ SEM } & \multirow[b]{2}{*}{$P<$} \\
\hline & $\begin{array}{l}\text { Control } \\
(\mathrm{n}=22)\end{array}$ & $\begin{array}{l}\text { DFM } \\
(\mathrm{n}=22)\end{array}$ & & \\
\hline \multicolumn{5}{|l|}{$\begin{array}{l}\text { Prepartum } \\
\text { BW . kg }\end{array}$} \\
\hline \multicolumn{5}{|l|}{$\mathrm{BW}, \mathrm{kg}$} \\
\hline Initial & 758 & 714 & 19 & \\
\hline Final & 757 & 715 & 19 & NS \\
\hline Change & -1 & +1 & - & - \\
\hline \multicolumn{5}{|l|}{$\mathrm{BCS}$} \\
\hline Initial & 3.6 & 3.5 & 0.12 & NS \\
\hline Final & 3.6 & 3.5 & 0.11 & NS \\
\hline Change & 0 & 0 & - & - \\
\hline \multicolumn{5}{|c|}{ Postpartum } \\
\hline \multicolumn{5}{|c|}{ BW, kg } \\
\hline Initial & 679 & 652 & 17 & NS \\
\hline Final & 627 & 613 & 16 & NS \\
\hline Change & -52 & -39 & - & - \\
\hline \multicolumn{5}{|l|}{ BCS } \\
\hline Initial & 3.5 & 3.5 & 0.11 & NS \\
\hline Final & 3.2 & 3.2 & 0.08 & NS \\
\hline Change & -0.3 & -.3 & - & - \\
\hline
\end{tabular}

${ }^{1}$ Probios TC (Chr. Hansen, Milwaukee, WI). The DFM contained $5 \times 10^{9} \mathrm{cfu}$ of yeast and $5 \times 10^{9} \mathrm{cfu}$ of bacteria ( 2 specific Enterococcus faecium strains).

${ }^{2}$ Cows received treatment from $21 \pm 3$ d prior to expected calving date through wk 10 postpartum.

ier compared with DFM-fed cows. Regardless, the relative BW loss was not different. Both groups sustained very low and similar body condition losses.

Two sets of twins were born to control cows, and one set was born to DFM-supplemented cows (Table 6). Cows receiving DFM had 13.6 vs. $9.1 \%$ retained placentas. The incidences of metritis $(13.6 \%)$, ketosis $(9.1 \%)$, and displaced abomasums were similar between treatments.

Table 6. The effect of direct-fed microbial ${ }^{1}$ (DFM) supplementation on postpartum health disorders

\begin{tabular}{lccc}
\hline & \multicolumn{2}{c}{ Treatment } & \\
\cline { 2 - 3 } Variable & $\begin{array}{l}\text { Control } \\
(\mathrm{n}=22)\end{array}$ & $\begin{array}{l}\text { DFM } \\
(\mathrm{n}=22)\end{array}$ & $P$ \\
\hline \multirow{2}{*}{ Twins } & $-[\%$ (number of & incidences $)]-$ & \\
Retained placenta & 9.1 & 4.5 & NS \\
Metritis & 9.1 & $(1)$ & NS \\
Ketosis & $(2)$ & 13.6 & NS \\
Displaced abomasum & 13.6 & $(3)$ & NS \\
& $(3)$ & 13.6 & NS \\
& 9.1 & $(3)$ & \\
\hline
\end{tabular}

${ }^{1}$ Probios TC (Chr. Hansen, Milwaukee, WI). The DFM contained $5 \times 10^{9} \mathrm{cfu}$ of yeast and $5 \times 10^{9} \mathrm{cfu}$ of bacteria ( 2 specific Enterococcus faecium strains). 
Table 7. The effect of direct-fed microbial ${ }^{1}$ (DFM) supplementation on blood parameters pre- and postpartum

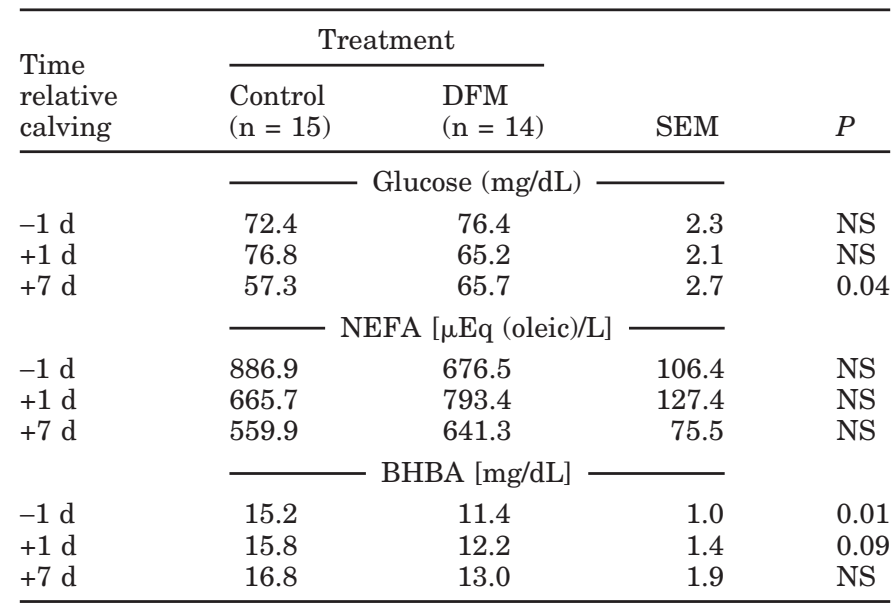

${ }^{1}$ Probios TC (Chr. Hansen, Milwaukee, WI). The DFM contained $5 \times 10^{9} \mathrm{cfu}$ of yeast and $5 \times 10^{9} \mathrm{cfu}$ of bacteria ( 2 specific Enterococcus faecium strains).

During the prepartum period, blood glucose was similar between treatments (Table 7). On d 1 postpartum, there were also no significant differences; however, by d 7, cows consuming DFM had higher $(P<0.05)$ blood glucose than did control cows. There were no differences in NEFA concentrations between treatments for any of the times measured. However, during the prepartum period, there was a numerical tendency for DFM cows to have lower NEFA, and during the postpartum period, there was a numerical tendency for DFM cows to have have higher NEFA concentrations, when compared with controls. During the prepartum period, BHBA was lower $(P<0.01)$ for cows supplemented with DFM. Postpartum, these same trends continued.

\section{DISCUSSION}

Dry matter intake and milk production responses were consistent with those demonstrated in a previous study (Nocek et al., 2003). Francisco et al. (2002) reported a reduction in DMI and no effect on milk yield and FCM when cows were supplemented with Propionibacteria in the first 12 wk postpartum. Other combinations of microbials (McGilliard and Stallings, 1998) have shown increases in milk production. Gomez-Alarcon et al. (1991) demonstrated an increase in milk yield to diets supplemented with Aspergillus oryzae, whereas several studies (Harris et al., 1983; Denigan et al., 1992; Sievert and Shaver, 1993) have shown no response. Yeast supplementation has been shown to increase DMI (Erasmus et al., 1992; Adams et al., 1995) and milk (Williams et al., 1991; Wohlt et al., 1991; Piva et al., 1993) in some studies with no effect in others (Harris et al., 1992; Swartz et al., 1994; Wohlt et al., 1998). The modes of action of the yeast and fungi as well as other bacteria can be quite variable, ranging from enhanced cellulolytic bacterial proliferation by providing unknown growth factors to increased substrate availability through added enzymatic digestion (Martin and Nesbit, 1992). One possible mode of action for DFM in the present study is that they are providing a tonic level of lactic acid production in the rumen, which is used by specific lactic acid-utilizing bacteria. The result would be the production of sustained low and nondetectable concentrations of lactic acid in the rumen, supporting a basal level of lactic acid utilizers, which would tend to stabilize and increase $\mathrm{pH}$, particularly nadir levels (Owens et al., 1998; Nocek et al., 2002). These rumen microbial changes support an environment conducive to increased forage digestibility and DMI, thus attributing to the production response. This study incorporated digestibility information to identify the ruminal response with a high corn silage diet as compared with the previous study (Nocek et al., 2003), which contained a high proportion of haylage.

McGilliard and Stallings (1998) demonstrated a milk fat depression when supplementing cows with a combination of microbials; others (Higginbotham et al., 1994; Wohlt et al., 1998; Francisco et al., 2002) showed no reponse. In the present study, milk fat percentage was lower for cows supplemented with DFM; there was no effect on milk protein. This is inconsistent with the previous study (Nocek et al., 2003), where fat percentage was unaffected and protein was increased when the same product was tested. However, because, in the study, milk production was higher and fat yield was lower and did not differ, a probable cause for reduction in fat is dilution. Previous lactation fat percentages for the same cows assigned to this study tended to be higher for control cows than for DFM-supplemented cows (3.96 vs. $3.75 \%$ ). In the assignment process, cows were balanced by previous lactation 305-d mature equivalent milk production, and no consideration was given to the fat test. It should be pointed out that although milk fat percentage was lower for DFM-supplemented cows compared with controls, there was no fat depression for either regimen. The primary difference between control and DFM-supplemented cows for fat percentage was associated with the first 2 wk postpartum (Figure 2).

Elevated plasma glucose postpartum can be reflective of greater positive energy balance or the provision of more glucogenic precursors (Vazquez-Anon et al., 1997). Francisco et al. (2002) reported that the addition of Propionibacteria had no effect on plasma glucose. Ghorbani et al. (2002) reported no effect of a Propionibacterium and $E$. faecium on any blood variables in feedlot cattle. The prevalence of higher lactose concen- 
trations in conjunction with higher milk production would correspond with the higher level of glucose in the blood. However, in the present study, the provision of nutrients appears to be associated with both higher intakes and greater partitioning of nutrients toward milk, as there was no effect of treatment on BW or BCS change and NEFA tended to be higher for DFMsupplemented cows. This was suspected in the previous study (Nocek et al., 2003); however, no BW or BCS were recorded. Although there were no statistical differences in NEFA levels, DFM-supplemented cows showed 19.2 and 14.5\% higher concentrations on $\mathrm{d} 1$ and 7 postpartum, respectively, compared with control cows. Francisco et al. (2002) reported similar plasma NEFA results in the first week postpartum for supplemented cows. Higher postpartum plasma NEFA levels were negatively correlated with prepartum intake (Grummer, 1995), which is inconsistent with the results of this study. The reason for reduced BHBA levels for supplemented cows is not entirely understood but may be associated with more efficient use of nutrients for productive purposes. Elevated BHBA levels suggest that fatty acids are being oxidized and used as fuel (Drackley, 1999), suggesting that cows may be in greater negative energy balance (Lean et al., 1992).

\section{CONCLUSIONS}

Cows receiving a specific supplemental DFM produced more milk and consumed more DM during the pre- and postpartum periods. However, they experienced a lower, but not depressed fat percentage compared with non-supplemented cows. Ruminal digestion of forage DM was increased in cows supplemented with DFM. The differences in elevation in blood glucose were increased, as was milk lactose concentration and milk production. However, NEFA and BHBA levels provided little insight into fatty acid mobilization and fat synthesis.

\section{REFERENCES}

Adams, A. L., B. Harris, H. H. Van Horn, and C. J. Wilcox. 1995. Effects of varying forage types on milk production responses to whole cottonseed, tallow and yeast. J. Dairy Sci. 78:573-581.

Beharka, A. A., and T. G. Nagaraja. 1993. Effects of Aspergillus oryzae extract $\left(\right.$ Amaferm $^{\circledR}$ ) on in vitro fiber digestion. J. Dairy Sci. 76:812-18.

Denigan, M. E., J. T. Huber, G. Alhadhrami, and A. A. Dehneh. 1992. Influence of feeding varying levels of Amaferm ${ }^{\circledR}$ on performance of lactating dairy cows. J. Dairy Sci. 75:1616-1621.

Drackley, J. K. 1999. Biology of dairy cows during the transition period: The final frontier? J. Dairy Sci. 82:2259-2273.

Erasmus, L. J., P. M. Botha, and A. Kristner. 1992. Effect of yeast culture supplement on production, rumen fermentation, and duodenal nitrogen flow in dairy cows. J. Dairy Sci. 75:3056-3065.

Francisco, C. C., C. S. Chamberlain, D. N. Waldner, R. P. Wettemann, and L. J. Spicer. 2002. Propionibacteria fed to dairy cows: Effects on energy balance, plasma metabolites and hormones, and reproduction. J. Dairy Sci. 85:1738-1751.

Ghorbani, G. R., D. P. Morgavi, K. A. Beauchemin, and J. A. Z. Leedle. 2002. Effects of bacterial direct-fed microbials on ruminal fermentation, blood variables, and the microbial populations of feedlot cattle. J. Anim. Sci. 80:1977-1985.

Gomez-Alarcon, R. A., J. T. Huber, G. E. Higginbatham, F. Wiersma, D. Ammon, and B. Taylor. 1991. Influence of feeding an Aspergillus oryzae culture on milk yields, eating patterns and body temperature of lactating cows. J. Anim. Sci. 69:1733-1740.

Grummer, R. R. 1995. Impact of changes in organic nutrient metabolism on feeding the transition cow. J. Anim. Sci. 73:2320-2327.

Harris, B., Jr., D. E. Dorminey, W. A. Smith, H. H. Van Horn, and C. J. Wilcox. 1992. Effects of feather meal at two protein concentrations and yeast culture on production parameters in lactating dairy cows. J. Dairy Sci. 75:3524-3530.

Harris, B., Jr., H. H. Van Horn, K. E. Manookian, S. P. Marshal, M. J. Taylor, and C. J. Wilcox. 1983. Sugarcane silage, sodium hydroxide- and steam pressure-treated sugarcane bagasse, corn silage, cottonseed hulls, sodium bicarbonate, and Aspergillus oryzae product in complete rations for lactating cows. J. Dairy Sci. 66:1474-1485.

Higginbotham, G. E., C. A. Collar, M. S. Aseltine, and D. L. Bath. 1994. Effect of yeast culture and Aspergillus oryzae extract on milk yield in a commercial dairy herd. J. Dairy Sci. 77:343-348.

Knowlton, K. F., J. M. McKinney, and C. Cobb. 2002. Effect of a directfed fibrolytic enzyme formulation on nutrient intake, partitioning, and excretion in early and late lactation Holstein cows. J. Dairy Sci. 85:3328-3335.

Lean, I. J., T. B. Farver, H. F. Trout, M. L. Bruss, J. C. Galland, R. L. Baldwin, C. A. Holmberg, and L. D. Weaver. 1992. Time series cross-correlation analysis of postparturient relation ships among serum metabolites and yield variables in Holstein cows. J. Dairy Sci. 75:1891-1898.

Martin, S. A., and D. J. Nesbit. 1992. Effect of direct-fed microbials on ruminal microbial fermentation. J. Dairy Sci. 75:1736-1744.

McCutcheon, S. N., and D. E. Bauman. 1986. Effect of chronic growth hormone treatment on responses to epinephrine and thyrotropinreleasing hormone on lactating cows. J. Dairy Sci. 69:44-51.

McGilliard, M. L., and C. C. Stallings. 1998. Increase milk yield of commercial dairy herds fed a microbial and enzyme supplement. J. Dairy Sci. 81:1353-1357.

Nocek, J. E. 1988. In situ and other methods to estimate ruminal protein and energy digestibility: A review. J. Dairy Sci. 71:2051-2062.

Nocek, J. E., W. P. Kautz, J. A. Z. Leedle, and J. G. Allman. 2002. Ruminal supplementation of direct-fed microbials on diurnal $\mathrm{pH}$ variation and in situ digestion in dairy cattle. J. Dairy Sci. 85:429-433.

Nocek, J. E., W. P. Kautz, J. A. Z. Leedle, and E. Block. 2003. Directfed microbial supplementation on the performance of dairy cattle during the transition period. J. Dairy Sci. 86:331-335.

Owens, F. N., D. S. Secrist, W. J. Hill, and D. R. Gill. 1998. Acidosis in cattle. A review. J. Anim. Sci. 76:275-286.

Piva, G. S., S. Belladonna, G. Fusconi, and F. Sicbaldi. 1993. Effects of yeast on dairy cow performance, ruminal fermentation, blood components, and milk manufacturing properties. J. Dairy Sci. $76: 2717-2722$.

SAS JMP. 1996. Software: Statistical Discovery Software. Version 4.0.4. SAS Inst., Inc.,Cary, NC.

Sechen, S. J., F. R. Dunshea, and D. E. Bauman. 1990. Somatotropin in lactating cows-Effect on response to epinephrine and insulin. Am. J. Physiol. 258:E582-E588.

Sievert, S. J., and R. D. Shaver. 1993. Carbohydrate and Aspergillus oryzae effects on intake, digestion, and milk production of dairy cows. J. Dairy Sci. 76:245-254.

Stokes, M. E., C. S. Davis, and G. G. Koch. 1995. Logistic regression I: Dichotomous response. Pages 163-214 in Categorical Data Analysis Using the SAS System. SAS Inst. Inc., Cary, NC.

Sullivan, H. M., and S. A. Martin. 1999. Effects of Saccharomyces cerevisiae culture on in vitro mixed ruminal microorganism fermentation. J. Dairy Sci. 82:2011-2016. 
Swartz, D. L., L. D. Muller, G. W. Rogers, and G. A. Varga. 1994. Effect of yeast culture on performance of lactating dairy cows: A field study. J. Dairy Sci. 77:3073-3080.

Van Soest, P. J., C. J. Sniffen, D. R. Mertens, D. G. Fox, P. H. Robinson, and U. Krishnamoothy. 1982. A net protein system for cattle: The rumen submodel for nitrogen. Page 265 in Protein Requirements for Cattle. Oklahoma State Univ. MP109. Oklahoma State Univ., Stillwater.

Vazquez-Anon, M., S. J. Bertics, and R. C. Grummer. 1997. The effect of dietary energy during mid to late lactation on liver triglyceride and lactation performance of dairy cows. J. Dairy Sci. 80:25042512 .
Williams, P. E. V., C. A. G. Tait, G. M. Innes, and C. J. Newbold. 1991. Effects of inclusion of yeast culture (Saccharomyces cerevisiae plus growth medium) in the diet of dairy cows on milk yield and forage degradation and fermentation patterns in the rumens of steers. J. Dairy Sci. 69:3016-3026.

Wohlt, J. E., T. T. Corcione, and P. K. Zajac. 1998. Effect of yeast on feed intake and performance of cows fed diets based on corn silage during early lactation. J. Dairy Sci. 81:1345-1352.

Wohlt, J. E., A. D. Finkelstein, and C. H. Chung. 1991. Yeast culture to improve intake, nutrient digestibility and performance of dairy cattle during early lactation. J. Dairy Sci. 74:1395-1400. 